\title{
Sustainable Banking and Bank Performance
}

\author{
Lilik Handajani ${ }^{1 *}$, Akram² $^{2}$, Ahmad Rifai ${ }^{3}$
}

AFFILIATION:

1,2,3 Faculty of Economics and Business, Universitas Mataram, Indonesia

*CORRESPONDENCE:

lilikhandajani@unram.ac.id

THIS ARTICLE IS AVAILABLE IN:

https://ojs.unud.ac.id/index.php/jiab

DOI:

10.24843/JIAB.2021.v16.i01.p12

\section{CITATION:}

Handajani, L., Akram, \& Rifai, A. (2021). Sustainable Banking and Bank Performance. Jurnal IImiah Akuntansi dan Bisnis, 16(1), 173186.

\section{ARTICLE HISTORY}

Received:

07 November 2020

Revised:

22 December 2020

Accepted:

05 January 2021

\begin{abstract}
This research aims to examine the impact of sustainable banking practices and bank characteristics on bank performance. Structural equation models were used to analyze 11 banks listed on the Indonesia Stock Exchange that published sustainability reports consistently during the periods of 2015-2018. Results indicate that while the internalization of sustainability issues in banking business practices does not have a significant impact on bank performance, the characteristics of a bank, which are reflected by institutional and foreign ownership and bank age, have a significant effect on bank financial and nonfinancial performance. The implications of sustainable banking practices are indicated to gain legitimacy from regulators for the existence of financial entities and meet stakeholder expectations, which in practice require trade-off of interests among stakeholder groups.
\end{abstract}

Keywords: sustainable banking, bank performance, bank characteristic

\section{Introduction}

Nowadays, there are many firms that freely adopt and implement sustainability practices widely to meet the stakeholder demand and expectation. In financial sector as banking, global pressure is also encouraging banks to be more active in business sustainability, such as economic, environmental and social aspects. In responding to the sustainability issue, bank would take different strategy, that affected by economic, social or environmental motives (Zimmermann, 2019). They might take a strategy to remain focus on financial business alone, even different strategy might be used on environmental and social issue, or even only support external sustainaility project through the allocated funds. As intermediary institution that raising and distributing people money, environmental and social issues might not be disobeyed. In banking business, reaching financial aspect alone could not represent bank performance, without evaluation on impact value of business activities towards environment and social, and also its' positive or negative performance (Usenko \& Zenkina, 2016). Similar argument to Afroz (2017), that top management should formulate policy and strategy of sustainable banking by internalizing environmental risks as a part of risks management. Besides financial risks, environmental and social issues should be considerate as important in business decision matters. It is because unsustainable corporate governance will lead to legal and credit risk and also reputation risks for the bank itself. 


\section{Handajani, Akram \& Rifai \\ Sustainable Banking and Bank Performance}

Study on sustainable banking was done in several relevants empirical researches. Handajani et al. (2019) had been assessed bank initiation with environmental issue in some of state-owned banks, and it was found that they have already developed sustainable banking concepts in their business, such as green product, green customer, green operational and green policy. Another study was done by Akter et al. (2018) on several commercial banks in Bangladesh regarding their bank sustainability report, and it found that more economic and social indicators were reported in sustainability report by banks compared to environmental issue. Most of the banks also reported economic indicator related with climate and financial implication of climate change compared to environmental aspect. Handajani (2019) examine any factors that lead to the implementation of green banking as an activity of sustainable banking in public banking in Indonesia. The result verified that there was an improvement existence of sustainable banking activity and, bank corporate governance represented by controlling function of supervisory boards, that having a positive role to support this system. In line with the research done by Rifat et al. (2016), stated that bank used sustainable banking as an important strategy along with their role towards social and environmental responsibility and also a sustainable ecological stability. Another result concluded that there was a positive perception of the banker to the adoption sustainable banking based on performance expectation, social competition and environmental care and also Central Bank regulation. Similar to previous research, Roy et al. (2015) found that bank practician and regulation gave a positive response towards concept and implementation initiative of sustainability issue done by Regulation Authority in Banking Sectors in Bangladesh. In different perspective, Rebai et al. (2012) was done a study on the implementation of sustainable banking in France, in the perspective of varied internal and eksternal stakeholder, such as manager, staff, regulator, shareholders, customers and society in large. The result showed that sustainable banking is an important issue in banking business that need the participation of all stakeholders to evaluate its application and need trade-off in its' implementation.

Some of the study related in banking sector in the perception of internal and eksternal stakeholder (Rifat et al., 2016; Roy et al., 2015; Rebai et al., 2012) or disclosure on sustainable information through bank publication report (Handajani, 2019; Handajani et al., 2019; Akter et al., 2017) and its' implementation motive (Zimmermann, 2019; Afroz, 2017), however it is still relatively limited studies examining the impact of the implementation of sustainable banking on bank performance. Sustainable issue still become a problem in the research of banking sector that usually focus on the use of information technology innovation and increasing quality of financial service itself, so it is an interesting area to be furtherly observed. In practical condition, there is still a debate of the positive contribution on the implementation of sustainable banking to the improvement of financial or nonfinancial bank. It is because a financial sector that is usually profit oriented, a financial performance is very crucial to keep the business to be survived among the others. In other hand, nonfinancial performance issue, social and environmental performance are also support banking performance in their business activity.

The aim of this research was to observe the effect of sustainable banking practice and bank characteristics to the financial and non financial performance in public banking listed in Indonesia Stock Exchange. Sustainable banking adoption was influenced by contextual factors (bank-specific factors), so that bank characteristics was 


\section{Handajani, Akram \& Rifai \\ Sustainable Banking and Bank Performance}

elaborated in this research. The result of this research could support sustainable banking practice, not only as short financial investment as cash outflow, but as a policy discretion that will affected impact in long term of bank performance. In regulation aspect, this research will support roadmap of sustainable finance for financial institution in Indonesia, as stated in regulation of The Financial Services Authority (OJK) number 51/POJK.03/2017. It will become a strategic issue for financial institution, especially for financial service, such as banking industry, that is directly get the impact of the regulation. The Financial Services Authority regulation on sustainable financial will pressure financial entities to consider environmental and social condition in making business decision to create sustainability financial institution in long term and financial stability globally.

Legitimacy Theory argumented that organization will try to meet the demand and expectation from the environment and society to have legitimate their activities. Within the context of sustainable banking, Islam et al. (2020) stated that an established bank would show more social information to keep market legitimate, while for a newly operating bank, it meant to approach the tertier customers, hoping it will reduced the gap by meeting the expectation of the society. Through other publication media, bank will inform information by yearly report to legitimate corporate action to meet the demand of sustainable practice by regulator. Agency Theory perspective argued there is trade-off between stakeholder group in internalized sustainable issue in banking business (Rebai et al., 2012). Corporate involvement in sustainable programs need financial support that in turn will reduce return rate for shareholders, even in the other hand could give benefit other non shareholder stakeholders.

Sustainable banking as an attempt of financial institution to sustainability is having a direct or non direct implication to the banking performance. Some of the studies reported that the implementation of sustainable issue in banking business practice will affect the bank performance, either in their financial nor financial. Within this skepticism of the impact of sustainable implementation on commercial bank, such as increasing expends that disturbing normal activities of the bank, Awino (2014) found a strong evidence that green banking as a sustainable program is having positive impact towards financial performance of the bank, so that government should make a policy regarding environmental conservation that should be adopted by commercial banks in Kenya. Similar with previous result, Roy et al. (2015) reported that the implementation of sustainable issue in banking business will give effect on bank performance, either financial or non financial performance. Through the implementation of pro environmental issue business practice, it could save resources that will lead to internal cost saving, that it will give positive contribution to reach financial performance for the bank. In contrary with previous study, Shah (2019) argued that agency problem should be considered in sustainable issue adoption, as environmental and social activities need extra costs that leads to competitive disadvantage, that in turn will give a negative effect to the bank performance.

Regarding with the impact of sustainable banking towards non financial performance, study of Shaumya \& Arulrajah (2017) reported that bank concern towards environment and social aspects through the sustainability implementation will give a chance to banks to get subsidies from the government, increase competitiveness and open investment opportunity by getting potential investors caring about these issues. This in line with the result of Simpson \& Kohers (2002), stated that to be a sustainable 


\section{Handajani, Akram \& Rifai \\ Sustainable Banking and Bank Performance}

bank with social performance actually need an extra costs but it does not lead to be unprofitable, as bank is also having a potency to have other competitiveness, that will give profitable stakeholder-relationship. Therefore, it can be argued that bank sustainable practice will affect bank performance, either financial or non-financial performance. It can be stated as following hypothesis:

$\mathrm{H}_{1 \mathrm{a}}$ : Sustainable Banking affected bank financial performance

$\mathrm{H}_{1 \mathrm{~b}}$ : Sustainable Banking affected bank non financial performance

Bank can be classified based on its' characteristics, such as the amount of asset owned, length of the operating period or ownership structure. A big bank with high numerous asset having visibility from society, including their role in sustainability aspect. Elston (2002) revealed that small company will grow faster facing nowadays changes compared to a big one. It may because a small company is easily adaptive towards changes and take role in using a new technology in their market, so that they are able to encourage operational efficiency that affect bank performance. This result support study done by Regehr \& Sengupta (2016), stated that firm size is not the factor that influence long period profitability, as bank-specific factor, such as business strategy, marketspecific factor, like market growth in operating bank environment, will give more profitability performance gain in long term.

To internalize sustainability issue, bank will build an innovative and sustainable financial products, that will give profitability and service quality for the customers, such as environmental risks in credit appraisal and technology adoption in operational activity or online service (Roy et al., 2015), that it will contribute to bank performance. Dealing with bank age, Alshehri (2016), found that a significant effect of bank age towards financial performance in case of increasing market margin, for length operation period will give higher reputation and wider experience facing new changes within business environment of the bank. Contrary to previous result, Haryati et al. (2019), stated that longer operation period of the bank do not show significant effect towards financial performance, even though bank age is an important attribute in one firm, as it showed the experience in managing the firm itself. In relation with bank ownership, study of Jiang et al. (2013) found that private bank presented improvement of bank performance, as there was changes on the composition of ownership that it will attract foreign investor, to improve long term banking efficiency. This will happen because there were technology and skill transfer in financial intermediation. The existence of controlling shareholder, and also type and combined ownership, such as financial institution, institutional investor and industry company will improve bank performance presented by increasing profit, decreasing return volatibility and lower default risk (Saghi-Zedek, 2016). Therefore, bank characteristic was predicted to affect financial and non financial performance, so that it can be described as following hypothesis:

$\mathrm{H}_{2 \mathrm{a}}$ : Bank characteristic affected bank financial performance

$\mathrm{H}_{2 b}$ : Bank characteristic affected bank non financial performance

\section{Research Method}

This research used an explanatory research approach, to know the effect of sustainable banking and bank characteristic towards bank performance by examining listed public banking in Indonesia Stock Exchange. This research used secondary data obtained from sustainability report published during the year 2015-2018. This research analyzed using exogenous and endogenous variables tests. Exogenous variable in this research was 
sustainable bank and firms characteristic, while the endogenous variable were financial and non financial performance of the bank. Sustainable banking in this research was reflected by economic indicator (Ec.SB), social (Soc.SB) and environmental (Env.SB) refer to sustainability indicator in Global Reporting Initiative (GRI) Standard (https://www.globalreporting.org), that the measurement using content analysis on the information content given in bank sustainability report.

Bank characteristic in this research was reflected by bank size, bank age and bank ownership structure of institutional (Inst.owner) and foreign ownership (Foreign.owner). Bank size (Size) was measure using logarithm natural of their total aset (In Total Asset), while bank age (Age) was measured using period length of bank operation as public firm. Bank performance was measured using Financial Performance (FP) and Non Financial Performance (NFP). Financial performance reflected with earning indicator (Return on Asset/ROA), Capital Adequacy Ratio/CAR, credit risks (Non performing Loan/NPL) and liquidity risks (Loan to Deposit ratio/LDR). Non financial performance was measured with third-party funds (TPF.MS) and credit market share (credit.MS) and CSR Award given to the bank (CSR Awards). Structural model examined using mathematical equation as follow:

$\begin{array}{ll}\mathrm{FP} & =\gamma_{1} \mathrm{SB}+\gamma_{2} \mathrm{BC}+\zeta 1 \ldots \ldots \ldots \\ \mathrm{NFP} & =\beta 1 \gamma_{3} \mathrm{SB}+\gamma_{4} \mathrm{BC}+\zeta_{2} .\end{array}$

Where:

FP $\quad=$ Financial Performance

NFP $\quad=$ Non-Financial Performance

SB = Sustainable Bank

$\mathrm{BC}=$ Bank Characteristic

$\gamma$ (gamma) $=$ Coefficient of effect of exogenous towards endogenous variable

$\zeta$ (zeta) = error term of structural model

Structural and measurement model (full model) of this research was presented in Figure 1.

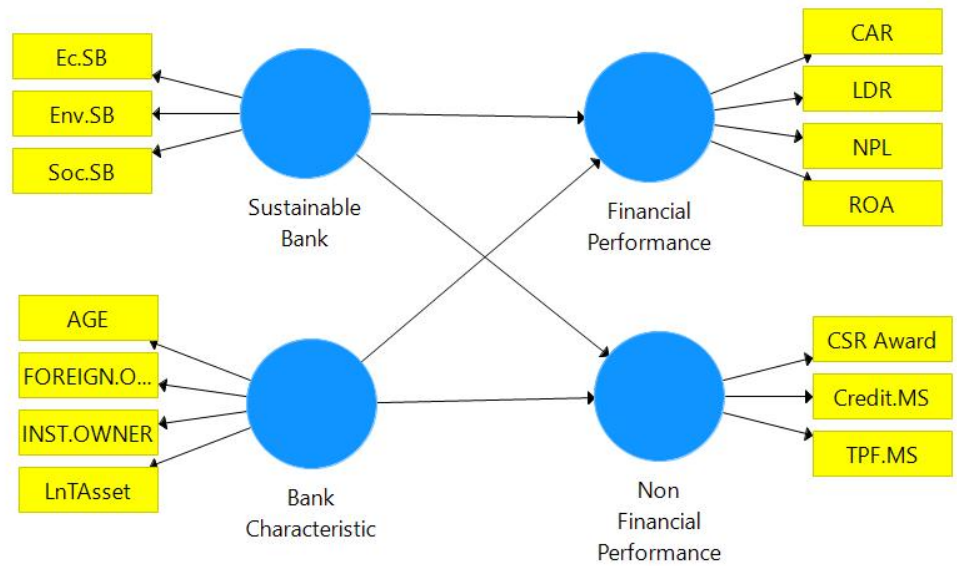

Figure 1. Structural Model and the Measurement

Source: Processed data, 2019 
Equation of measurement model (outer model) was used to unobservable variable was stated as below:

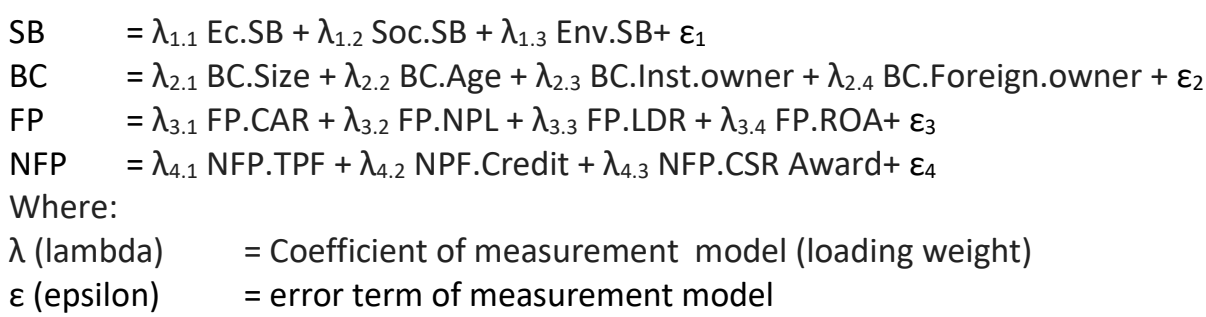

Decision taking criteria for outer model (structural model) was higher loading factor 0.7 for reflective indicator, while for inner model using two-tailed test with critical value $\mathrm{T}$ was higher than 1.96 . If $\mathrm{T}$ value was higher than 1.96 , then the hypothesis was accepted, but if lower then it could be rejected.

\section{Result and Discussion}

Result test on descriptive statistic of each latent variable and its' measurement indicators in this research was presented in Table 1. Economic indicator (Ec.SB) having higher average value (0.3830) compared to social indicator (Soc.SB) and environment (Env.SB). It indicated that in implementing sustainable issue, bank still focused on prioritized the economic aspect than social and environmental aspects. Based on bank characteristics, institutional ownership indicator was having a relative high average value $60.17 \%$ with the highest ownership $99.83 \%$ and the lowest was $13.39 \%$. The highest institutional ownership was expected to encourage a better sustainability through a collective monitoring which was done by the institution. Indicator on foreign ownership was averagely $46.41 \%$. Their existence was expected to give a tighter control on business activity dealing with performance achievement during short or long period as sustainability program. Other characteristic indicators were age and size of banks. The result of descriptive statistic showed that average bank age, starting from the beginning as public firm was 16.96 years. The operation period gave better experience for bank management to manage and understand business environmental. Bank size was measured with natural logarithm (In) total asset showed the highest value 20.91 and the lowest 13.14 with average value 17.5417, it meant that bank implemented sustainable practice was a big bank with high amount asset.

Average value of financial performance indicator (FP) namely ROA, CAR, LDR and NPL showed it was a healthy bank. Average value of ROA was 2.14, showed bank capability in managing their asset was fairly good. Average value of CAR was 19.39 classified as excellent, above the requirement of around $8 \%$ till $10 \%$, meant that bank was able to minimize the risks and have growth potency. NPL (Non-Performing Loan) indicator was averagely $2.87 \%$, was still under requirement of NPL less than $5 \%$, it meant that bank was well managed high risks credit. From loan to deposit ratio (LDR) indicator, with average value 89.75 , it meant that credit distributed compared to shareholders was still above ideal range by $75 \%-80 \%$. Variable on nonfinancial performance (NFP) showed that indicator of sustainability awards received by the bank (CSR Award) averagely reached 2 (two) awards with the highest 6 (six) awards, that meant sustainability programs obtained positive appreciate by having awards in this field. Other nonfinancial indicator, such as market share of third-party funds (TPF.MS) and 


\section{Handajani, Akram \& Rifai \\ Sustainable Banking and Bank Performance}

credit market share (Credit.MS) that were averagely having value respectively 6.22 and 7.02. The highest of third-party funds market share (TPF.MS) was 16.77 and 19.02 for credit market share. This represents the average bank has a competitive market share for credit and deposits of third-party funds in banking industry nationally.

The result of outer model evaluated fulfilled the convergen and discriminant validity. Based on the evaluation of measurement model, there were four indicators that having loading factor value less than 0.7 , so that it unloaded in latent variable reflected, that were bank size, LDR, NPL and CSR Award. After dropping was done to the four indicators there was recalculation test on second step outer model, and it was found that the environmental indicator (SR.Env) having loading factor value smaller than 0.7, so that it should be dropped as indicator. Recalculation model on the third measurement showed that all indicators in latent variable reflecting loading factor more than 0.7 , so that it fulfill the requirements of convergent validity. Measurement testing model using discriminant validity was evaluated by comparing all correlation among variable with quadrat root of AVE (Average Variance Extracted) or looking into correlation value of cross loading. Result of discriminant validity test showed that root value AVE of each variable block was higher than correlation value among other variables in the same line. Discriminant validity evaluation used a composite reliability, was also showed higher cronbach's alpha and composite reliability value more than 0.7 , that indicated reliability of measurement instrument in giving a consistent test result, so that it fulfill the discriminant validity of the measurement model of this research.

Structural test model or inner model was done to examine the model prediction ability and the relation among latent variable. Evaluation on goodness of fit of inner model was done to ensure that structural model build was reliable and valid (Hair et al., 2014). Testing of inner model can be done by evaluate coefficient of determination $\left(R^{2}\right)$, effect size $\left(f^{2}\right)$ and predictive relevance $\left(Q^{2}\right) . R^{2}$ or coefficient of determination, used to evaluate goodness of fit model to describe exogenous variable ability that affected endogenous variable. Coefficient of determination value of financial performance endogenous variable was 0.241 or $24.1 \%$ that could be described by exogenous variable of sustainable bank and bank characteristic. $R^{2}$ endogenous variable value of non

Table 1. Statistic Descriptive

\begin{tabular}{lrrrrr}
\hline Indicator & N & Minimum & Maximum & \multicolumn{1}{c}{ Mean } & Std. Deviation \\
\hline Ec.SB & 44 & 0.080 & 0.920 & 0.383 & 0.211 \\
Env.SB & 44 & 0.030 & 0.400 & 0.163 & 0.097 \\
Soc.SB & 44 & 0.090 & 0.880 & 0.328 & 0.182 \\
Size & 44 & 13.140 & 20.910 & 17.541 & 2.562 \\
Age & 44 & 2.600 & 29.300 & 16.960 & 8.458 \\
Foreign & 44 & 1.490 & 98.320 & 46.405 & 31.950 \\
Inst & 44 & 13.390 & 99.830 & 60.168 & 29.471 \\
ROA & 44 & -4.900 & 4.190 & 2.142 & 1.498 \\
CAR & 44 & 15.000 & 24.650 & 19.396 & 2.473 \\
NPL & 44 & 0.700 & 8.800 & 2.878 & 1.376 \\
LDR & 44 & 66.570 & 108.780 & 89.753 & 7.805 \\
TPF.MS & 44 & 1.430 & 16.770 & 6.215 & 4.686 \\
Credit.MS & 44 & 1.330 & 19.100 & 7.022 & 5.337 \\
CSR.Award & 44 & 0.000 & 6.000 & 1.772 & 1.395 \\
\hline SOurce:Proce
\end{tabular}

Source: Processed data, 2019 


\section{Handajani, Akram \& Rifai \\ Sustainable Banking and Bank Performance}

financial performance of bank was 0.157 , it meant that there was $15.7 \%$ variation of exogenous variable of bank characteristic and sustainability. Effect size $\left(f^{2}\right)$ value was used to measure the goodness of the model and the contribution of each exogenous variable towards endogenous variable (Hair et al., 2014). Contribution of exogenous variable of bank characteristic to the financial performance was 0.311 (fair), while the contribution of exogenous variable of bank characteristic to the non financial performance was 0.179 (fair). Meanwhile, contribution of sustainable bank towards financial and non financial performance showed a relatively low value, namely 0.020 and 0.007 . Evaluation result on predictive relevance $\left(Q^{2}\right)$ was done through blindfolding analysis to know the value of cross-validated communality. The result showed higher $\mathrm{Q}^{2}$ was more than zero, that was 0.171 for endogenous variable of financial performance and 0.103 for non financial. These result indicate that exogenous variable is good (appropriate) as predictor that is able to predict endogenous variable, so that this model meets the predictive relevance criteria. This summary of goodness of fit test was presented in Table 2 .

Result test of structural model or inner model showed that only exogenous variable of bank characteristic that gave significant effect to the financial and non financial performance of the bank, it showed by T statistic value higher than 1,96 and p-value smaller than 0,05 on two-tailed test. Therefore, this research was failed to prove that bank involvement on sustainability was able to significantly affected bank performance. Eventhough, this research proved that bank characteristic significantly affected their performance, either financial or non financial. The result concluded that the first hypothesis $\left(\mathrm{H}_{1 \mathrm{a}}\right.$ and $\left.\mathrm{H}_{1 b}\right)$ was rejected, while the second one $\left(\mathrm{H}_{2 \mathrm{a}}\right.$ and $\left.\mathrm{H}_{2 b}\right)$ was accepted. The summary of hypothesis test result was presented in Table 3.

Result of the first hypothesis test stated that sustainable banking do not have significant effect to financial and non financial performance of bank. This indicated that the implementation of sustainable issues on bank that reflected by economic and social indicators showed no significant impact to the bank performance, either on financial or non financial performance. This finding also indicated that the implementation of sustainability issues on banking indicated unbalancing of economic and social demand, but tended to focus on economic aspect. Therefore, the implementation of sustainable banking showed no significant impact on bank performance, either on financial performance reflected by ROA and CAR indicators, or non financial performance measured with indicator on third-party funds and credit market share. This result not in line with Roy et al. (2015) study stated that reaching bank financial performance

Table 2. Goodness of fit of Structural Model

\begin{tabular}{lccc}
\hline Latent Variable & $\begin{array}{c}\mathbf{R} \text { Square } \\
\left(\mathbf{R}^{\mathbf{2}}\right)\end{array}$ & $\begin{array}{c}\text { Effect } \\
\text { size } \\
\left(\mathbf{f}^{\mathbf{2}}\right)\end{array}$ & $\begin{array}{c}\text { Predictive } \\
\text { Relevance } \\
\left(\mathbf{Q}^{\mathbf{2}}\right)\end{array}$ \\
\hline Financial Performance & 0.241 & & 0.171 \\
Non-Financial Performance & 0.157 & & 0.103 \\
\hline Sustainable Bank $\rightarrow$ Financial Performance & & 0.020 & \\
Sustainable Bank $\rightarrow$ Non-Financial Performance & 0.007 & \\
Bank Characteristic $\rightarrow$ Financial Performance & & 0.311 & \\
Bank Characteristic $\rightarrow$ Non-Financial Performance & & 0.179 & \\
\hline Source Proces & & &
\end{tabular}

Source: Processed data, 2019 


\section{Handajani, Akram \& Rifai \\ Sustainable Banking and Bank Performance}

through pro environmental business will give positive contribution towards bank financial performance by saving resources that will lead to internal cost saving. This result did not support the study result done by Shaumya \& Arulrajah (2017), stated that bank attention towards environment and social aspects through sustainable implementation might improve nonfinancial performance, such as having subsidy from the government, improving banking competitiveness and opened investment from investor who have respect on environmental and social aspects.

Nevertheless, the research result supported the study of Aggarwal (2013), stated that firms sustainable level do not affected their financial performance, and the test result to the sustainable dimension (such as society, staffs, environment and management) gave inconclusive and varied effect. This result supported the study of Zyadat (2017), stated that sustainable dimension gave negative impact towards bank performance. Therefore, it is expected that bank will encourage investment and financial policy, that will maximize the profit for shareholders, and at the same time the aim of the social and environmental sustainability in the long term. This result is also supported Scholtens \& Klooster (2019) argumentation stated that bank sustainable performance will represent more impact to the lower default risk reducing their contribution to the other systemic risks than just to bank financial performance alone. This result also supported argumentation of Shah et al. (2019), stated that efficiency and productivity on sustainable bank was highly affected by external factors, such as the changes of government policy, technology development, and economic environment. In contrary, bank productivity in non-sustainable bank, will be triggered by internal factor, like ability to manage resources owned. This result indicated that implementation of bank sustainability needed investment cost to get competitiveness to create profitable stakeholder-relationship (Simpson \& Kohers, 2002). Besides, investment in sustainable program need cash-outflow that will lead to negative impact to the financial performance goal. This support the research done by Hossain \& Kalince (2014), stated that investment on sustainable bank was significantly affected financial performance, so that increasing banking activities tended to sustainable banking should be strengthen to create sustainable growth in long term period.

The result of the second hypothesis test on the effect of bank characteristic to the bank performance, either financial or non financial performance was supported in this research. Effect of bank characteristic to non financial performance showed significantly negative. Negative coefficient direction showed that when banking characteristic indicator increased will lead to decrease bank performance, and vice versa. It indicated that bank characteristic reflected by foreign and institutional ownership indicator and also bank age, were able to influence non financial performance, measured with third-party funds and credit market share. The existence of instutional ownership, $60 \%$, that was relatively high, will be able to pressure a collective

Table 3. Result of Hypotesis Test

\begin{tabular}{lccc}
\hline \multicolumn{1}{c}{ Relation of Latent Variable } & Coefficient & T Statistic & p-value \\
\hline Sustainable Bank $\rightarrow$ Financial Performance & -0.133 & 0.929 & 0.353 \\
Sustainable Bank $\rightarrow$ Nonfinancial Performance & -0.082 & 0.404 & 0.686 \\
Bank Characteristic $\rightarrow$ Financial Performance & -0.525 & 6.032 & $0.000^{*}$ \\
Bank Characteristic $\rightarrow$ Nonfinancial Performance & -0.420 & 3.175 & $0.000^{*}$ \\
\hline
\end{tabular}

*) Significant at $\alpha<0,05$ (two-tailed test)

Source: Processed data, 2019 


\section{Handajani, Akram \& Rifai \\ Sustainable Banking and Bank Performance}

control to make bank consider risks management to have bank growth chance while keeping bank health level as the regulation requirement. Institutional ownership was expected to do better monitoring and bank business performance, especially to maintain the competitive third-party funds and credit market share. In general, $40 \%$ foreign ownership could do controlling function to maintain the competitiveness in getting deposit from third-party funds and credit market share as the indicator of non financial performance of the bank. Bank age of 17 years as listed in Indonesia Stock Exchange indicated that bank have better managerial and understanding on financial business environment that showed by owned market share, so that bank could maintain their existence among their competitors. This result indicated that as a new issue in banking business, adoption of sustainable pactice is still a challenge in the operational activity, so that it become a crucial thing to be considered as a strategic issue in making decision to meet the success of bank performance during long term period.

Based on the test result, this research found that the negative significant effect of bank characteristic to the financial bank performance, reflected by ROA and CAR indicator. Institutional and foreign ownership and bank age as the indicators reflected bank characteristic gave a negative significant impact to the financial performance. The findings of this research described that the high existence of institutional ownership will pressure tighter collective control to the bank financial performance gain, even on the other side there was the demand to minimized the financial risks and remain well growth prospect of the bank. The existence of foreign and increasing institutional ownership will encourage bank practice not only to get financial performance, but also to keep bank healthy financially. Bank health should be supported by maintaining Capital Adequacy Ratio, around $8 \%-10 \%$, as determined by authority regulation. High Capital Adequacy ratio (CAR) was not always meant that bank financial performance was good. Even though, high CAR was certainly showed very good amount of capital, but it also showed that the capital was not well used in case of credit distribution. Therefore, it was important to maintain the ideal range of CAR that the capital should be used as productive credit distribution without ignoring their liquidity. Return on Asset (ROA) as profitability performance indicator indicated the ability of management to get return rate of risky asset as credit given. High ROA gain in banking activity showed well performance of bank profitability, but it should have followed with well managed of risky credit. The role of controlling of institutional and foreign ownership will limit the distribution of too aggressively credit distribution, with no proper risks management. Older bank age represented that longer period of operation will give better experience and ability of management in understanding banking business. Therefore, longer period of banking operation indicated better ability to manage owned asset to get income and also business risk management and credit risks. Therefore, growth chance through asset management should go along with an implementation of management risks and obedient towards the determined regulation. This result supported the study of Regehr \& Sengupta (2016) that big bank with bigger asset was not the main factor that influence long term profitability, as business strategy and banking sector market give an important role to drive the profitability performance gain in long period. This result also supported an argue of Elston (2002) study, that the effect of bank characteristic to the bank performance was not always dominated by big asset bank. As bank with relatively small asset was more adaptive towards changes and taking role in introducing new technology to the market to push operational efficiency that will affected bank 


\section{Handajani, Akram \& Rifai \\ Sustainable Banking and Bank Performance}

performance. This research proved that ownership structure and operating bank period gave significant effect to the financial performance gain. To be a healthy bank, the aim to reach financial gain should be followed by an attempt to fulfill the requirements as a healthy bank as the regulation stated.

Related to bank age as indicator bank characteristic, Alshehri (2016) stated that bank age have a significant effect on bank performance. The research argued that bank age that reflected the operational period length indicated that bank have a reputation and wider experience facing new changes and business environment. This argument supports the findings of previous study that bank's reputation and long experience in operations will encourage customer trust and loyalty so that the bank can gain market share, both for lending and deposits of third-party funds as indicators of non-financial performance in this study. However, this result was not in line with Haryati et al. (2019) study, stated that bank age did not show significant effect towards financial performance, even bank age was an important atribute in firms performance, since it showed management experience in managing the firms. Related to ownership as an indicator of bank characteristic, this result supported the argumentation of Jiang et al. (2013), stated that foreign and institutional ownership composition could improve bank efficiency during long period, as there were technology and skill transfer in financial intermediation. The results of this study support the previous research argument that the composition of institutional and foreign ownership structures will be able to play an effective role in encouraging better monitoring of a bank's long-term competitive advantage, including in maintaining and gaining market share among its competitors. Nevertheless, this result did not provide sufficient support for Saghi-Zedek (2016) findings, stated that there was ownership combination, such as financial institution, institutional investor, and industrial firms that would give a positive impact to improve bank performance showed by increasing profit, decreasing return volability and lower default risk, due to differences in the measurement of bank performance indicators.

This research findings gave theoritical, practice and policy implication. In theoritical implication argued the Legitimacy Theory in sustainable banking practice. Bank applied sustainable business showed an attempt to get operate legitimation by fulfilling the expectance of stakeholders or regulation about the implementation of sustainable in banking business. It was expected that bank was not only focus on economic gain in business policy, but they should also considerate social aspect and the effect to the environment. Sustainable banking needs financial investment, that cause conflict of interest among stakeholders and agency problem arised in the implementation. To internalized the sustainable issue that accommodate economic, social and environment demand in banking business, it need the involved stakeholders. This practical implication of this research was useful for management to disclose sustainability issues in corporate report, such as economic, social and environmental indicators to give a transparency to the external parties and relevant stakeholders. Adoption on sustainability in bank business was done to minimize financial, and also social and environment risks so that sustainability consideration should become strategic issue in banking business. The implication of this research was to support the regulation on the implementation of pro environmental policy, such as sustainable finance in banking activity was to support sustainability development during long period. 


\author{
Handajani, Akram \& Rifai \\ Sustainable Banking and Bank Performance
}

\title{
Conclusion
}

This research finding showed that internalization sustainability issues in banking business practice did not give a significant effect on financial or non-financial performance. However, the result of this study found that bank characteristics have a significant effect on bank performance, both financial or non-financial performance. This result indicated that bank characteristic reflected by collective control of institutional and foreign ownership and the length period of bank operation would give significant effect to the achievement of bank performance, even in practical should be followed with fulfilling the compliance of bank health requirements stated by regulation and applying banking risk management to create stakeholder value in long term. The research findings indicated that sustainable bank was still a challenge in operational practice, since it is a long term policy and investment, that their performance gain could not be measured in short time period, so that it will give a negative impact to the short term performance gain. This research finding indicated that sustainable bank was more encouraging by regulation for financial institution to get operating legitimation and maintaining bank existence to meet the demand and expectation of stakeholders. This result had several limitations related to the numbers of observed banks, as there were just several banks performed sustainability reporting issue. Therefore, in the next study, we need to elaborate other report media, such as internet financial reporting or Corporate Social Responsibility of banks. This research was also having relatively limited proxies reflecting financial and non-financial performance, so that the next study should elaborate risk-taking, return volatility, bank reputation, the growth number of consumers, or sustainable awards as indicators of bank performance. The impact of sustainable bank to the bank performance gave an inconclusive result to measure short term bank performance, so that the future research should consider time lag test with longer period of observation to improve robustness of research result.

\section{References}

Afroz, N. N. (2017). Green banking initiatives of Islamic Bank Bangladesh Limited. Global Journal of Management and Business Research, 1(1), 1-8.

Aggarwal, P. (2013). Impact of sustainability performance of company on its financial performance: A study of listed Indian companies. Global Journal of Management and Business Research Finance, 13(11), 61-70.

Akter, N., Siddik, A. B., \& Mondal, M. S. Al. (2017). Sustainability reporting on green financing : A study of listed private sustainability. Journal of Business and Technology, XII(July-December), 14-27.

Alshehri, A. F. (2016). An examination of the relationship between size, age and financial performance in Islamic banks : Evidence from around the world. Journal of Islamic Economics Banking and Finance, 12(4), 155-178. https://doi.org/10.12816/0050984

Awino, O. (2014). The Relationship Between Green Banking and Financial Performance of Commercial Banks in Kenya. University of Nairobi.

Elston, J. (2002). An examination of the relationship between firm size, growth and liquidity in the Neuer Markt. Bundesbank Series 1 Discussion Paper, (2002).

Hair, J. F., Hult, G. T. m., Ringle, C. M., \& Sarstedt, M. (2014). A Primer on Partial Least Squares Structural Equation Modeling (PLS-SEM) (Vol. 46). California: Sage Publications. https://doi.org/10.1016/j.Irp.2013.01.002 


\section{Handajani, Akram \& Rifai \\ Sustainable Banking and Bank Performance}

Handajani, L. (2019). Corporate governance and green banking disclosure: A study on banks in Indonesia. Jurnal Dinamika Akuntansi dan Bisnis, 6(2), 121-136.

https://doi.org/10.24815/jdab.v6i2.12243

Handajani, L., Rifai, A., \& Husnan, L. H. (2019). Study of initiation of green banking practices on State-owned Banks. Jurnal Economia, 15(1), 1-16.

https://doi.org/10.21831/economia.v15i1.21954

Haryati, N., Burhany, D. I., \& Suhartanto, D. (2019). Assessing the profitability of Islamic banks: The role of bank age and bank performance. IOP Conference Series: Materials Science and Engineering, 662(6). https://doi.org/10.1088/1757899X/662/6/062014

Hossain, S., \& Kalince, T. A. (2014). Green Banking Nexus Banks' Performance. Swiss Journal of Research in Business and Social Science, 1(3), 1-16. Retrieved from http://www.sjrbss.com/current-issue

Iqbal, M., Suviitawat, A., Nisha, N., \& Rifat, A. (2016). The role of commercial banks in green banking adoption: a Bangladesh perspective. International Journal of Green Economics, 10(3/4), 226. https://doi.org/10.1504/ijge.2016.10002862

Islam, M. T., Kokubu, K., \& Nishitani, K. (2020). Corporate social reporting in the banking industry of Bangladesh: a test of Legitimacy Theory. Social Responsibility Journal. https://doi.org/10.1108/SRJ-05-2019-0185

Jiang, C., Yao, S., \& Feng, G. (2013). Bank ownership, privatization, and performance : Evidence from a transition country. Journal of Banking and Finance 37 (9), 33643372. https://doi.org/10.1016/j.jbankfin.2013.05.009

Rebai, S., Azaiez, M. N., \& Saidane, D. (2012). Sustainable performance evaluation of banks using a multi-attribute utility model: An application to French banks.

Procedia Economics and Finance, 2(March), 363-372.

https://doi.org/10.1016/s2212-5671(12)00098-6

Regehr, K., \& Sengupta, R. (2016). Has the relationship between bank size and profitability changed? Economic Review, (Q II), 49-72.

Roy, M. K., Sarker, M. A. S., \& Parvez, S. (2015). Sustainability in Banking Industry : Which way to move? ASA University Review, 9(2), 53-69.

Saghi-Zedek, N. (2016). Product diversification and bank performance: Does ownership structure matter? Journal of Banking and Finance, 71, 154-167. https://doi.org/10.1016/j.jbankfin.2016.05.003

Scholtens, B., \& Klooster, S. (2019). Sustainability and bank risk. Palgrave Communications, 5(105), 1-8. https://doi.org/10.1057/s41599-019-0315-9

Shah, A. A., Wu, D., \& Korotkov, V. (2019). Are sustainable banks efficient and productive? A data envelopment analysis and the Malmquist productivity index analysis. Sustainability (Switzerland), 11(8), 1-19.

https://doi.org/10.3390/su11082398

Shaumya, S., \& Arulrajah, A. (2017). The Impact of Green Banking Practices on Bank's Environmental Performance: Evidence from Sri Lanka. Journal of Finance and Bank Management, 5(1), 77-90. https://doi.org/10.15640/jfbm.v5n1a7

Simpson, W.G., \& Kohers, T. (2002). The link between corporate social and finnacial performance: Evidence from the banking industry. Journal of Business Ethics, 35 (2), 97-109.

Usenko, L., \& Zenkina, I. (2016). Modern Trends and Issues of Corporate Reporting Data Disclosure on Organization Activities. Mediterranean Journal of Social Sciences, 
Handajani, Akram \& Rifai

Sustainable Banking and Bank Performance

7(3), 212-220. https://doi.org/10.5901/mjss.2016.v7n3p212

Zimmermann, S. (2019). Same same but different: How and why banks approach sustainability. Sustainability (Switzerland), 11(8), 1-20.

https://doi.org/10.3390/su11082267

Zyadat, A. A. H. (2016). The impact of sustainability on the financial performance of Jordanian Islamic Banks. International Journal of Economics and Finance, 9(1), 55.

https://doi.org/10.5539/ijef.v9n1p55 